\title{
Microbial and Sensory Qualities of Modified Atmosphere Packaged "Ready To Eat" Orange Segments
}

\author{
E. Gowthami ${ }^{*}$, K. Lavanya ${ }^{1}$, Sivala Kumar ${ }^{2}$ and M. Sandhya ${ }^{3}$ \\ ${ }^{1}$ Department of Agricultural Process and Food Engineering, College of Agricultural \\ Engineering, Bapatla - 522 101, India \\ ${ }^{2}$ College of Food Science and Technology, Bapatla, India \\ ${ }^{3}$ Department of Food Chemistry and Nutrition, College of Home Science, Guntur, India \\ *Corresponding author
}

\begin{tabular}{|c|c|}
\hline & A B S T R A C T \\
\hline $\begin{array}{l}\text { Oranges, } \\
\text { Citrus sinensis. } \\
\text { LDPE, } \\
\text { PP and } \\
\text { PVC pouches. }\end{array}$ & \multirow{3}{*}{$\begin{array}{l}\text { Oranges were sanitized, dried, peeled, segmented and then dipped in citric acid solution } \\
\text { (food grade) at } 2 \%(\mathrm{w} / \mathrm{v}) \text {. Citric acid treated and untreated orange segments were packed } \\
\text { with different packaging materials i.e., LDPE, PP and PVC pouches under three different } \\
\text { gas compositions i.e., Gas composition } 1\left(\mathrm{G}_{1}: 8 \% \mathrm{O}_{2}+15 \% \mathrm{CO}_{2}+77 \% \mathrm{~N}_{2}\right) ; \mathrm{Gas} \\
\text { composition } 2\left(\mathrm{G}_{2}: 5 \% \mathrm{O}_{2}+10 \% \mathrm{CO}_{2}+85 \% \mathrm{~N}_{2}\right) ; \mathrm{Gas} \text { composition } 3\left(\mathrm{G}_{3}: 3 \% \mathrm{O}_{2}+5 \%\right. \\
\left.\mathrm{CO}_{2}+92 \% \mathrm{~N}_{2}\right) \text { using advanced vacuum packaging machine. After packaging, the sealed } \\
\text { covers and control samples of orange segments were immediately stored at } 5{ }^{0} \mathrm{C} \text {. At an } \\
\text { interval of } 4 \text { days, the stored samples of orange segments were taken for their quality } \\
\text { evaluation i.e., microbial load and sensory evaluations were also conducted to establish } \\
\text { consumer acceptance. Results showed that the product acceptability and sensory attributes } \\
\text { of untreated and treated orange segments under } \mathrm{G}_{2} \text { gas composition were limited to } 20 \text { and } \\
25 \text { days and the results suggested that quality was better in orange segments packed in } \\
\text { LDPE covers under } \mathrm{G}_{2} \text { gas composition for } 25 \text { days. }\end{array}$} \\
\hline Article Info & \\
\hline $\begin{array}{l}\text { Accepted: } \\
\text { 22 January } 2017 \\
\text { Available Online: } \\
\text { 10 February } 2017\end{array}$ & \\
\hline
\end{tabular}

\section{Introduction}

Among citrus fruits, orange (Citrus sinensis) belongs to Rutaceae family evolved in the South East Asia and has excellent nutritive, medicinal and food values. The current production level in India is over 2906.3 thousand metric tonnes and the total area under orange cultivation is around 311.2 thousand hectares, which accounts for $3.6 \%$ of total fruit production (Kumar et al., 2013).

Ready to eat oranges are very relevant since the fresh market is often limited and also inconvenience of peeling, especially due to the release of essential oils (Groppo et al.,
2009). The fact that oranges have specific physiological (non-climacteric), morphological (structure into wedges) characteristics and are chilling-tolerant make them suitable for minimally processed product (Plaza et al., 2011). The oranges have ideal conditions for being prepared as RTU/RTE products, since their distribution in segments allows the sectioning of the fruit without modifying the integrity of the vesicular structure (Pretel et al., 1998).

When citrus fruits are peeled and the outer protective layer removed, occurrence of 
undesirable physiological changes in them and the fresh cells rich in water, sugars, and organic acids are exposed. The leakage of nutrients will promote microbial growth and the damaged tissue will also provide a portal of entry for establishment of microbes. It may cause an increase in respiration, biochemical changes and microbial spoilage and therefore, detrimental effects on food quality. The implementation of optimum storage (refrigerated) conditions through modified atmospheres with citric acid dipping can be quite effective, thus maximizing product shelf life and quality.

Citric acid dipping acts as a pretreatment and barrier against moisture loss and gas exchanges and can be a carrier of other components like antimicrobials, which can help to extend the shelf-life of the ready to eat fruit (Piga et al., 2002; Saxena et al., 2008). In modified atmosphere (MA) applications, the $\mathrm{O}_{2}$ and $\mathrm{CO}_{2}$ concentrations are modified initially and then change dynamically depending on respiration rate of product and the permeability of the film surrounding the produce to provide gas equilibrium inside the package. Reduced $\mathrm{O}_{2}$ and/or enriched $\mathrm{CO}_{2}$ levels reduce respiration and decrease ethylene production, inhibit or delay enzymatic reactions, lessen the physiological disorders and preserve the product from quality losses and also inhibit growth of aerobic spoilage organisms.

Khazaei et al., (2011) studied the effect of modified atmosphere packaging (MAP) on physical, chemical, and sensory properties of bitter orange stored at $4^{0} \mathrm{C}$ for 20 days. Bitter oranges were sanitized, peeled, segmented and packed under normal $\left(21 \% \mathrm{O}_{2}+79 \% \mathrm{~N}_{2}\right.$ as passive MAP) and two modified atmospheres $\left(20 \% \mathrm{O}_{2}+20 \% \mathrm{CO}_{2}+60 \% \mathrm{~N}_{2}\right.$ as active MAP1 and 60\% $\mathrm{O}_{2}+30 \% \mathrm{CO}_{2}+$ $10 \% \mathrm{~N}_{2}$ as active MAP2) in polyethylene (PE) trays. In general, there was no significant effect of MAP observed in chemical properties. The firmness values increased at all applications. Bitter orange segments remained viable for 20 days under enriched oxygen $(60 \%)$ and less than 20 days under active (20\% oxygen) and passive MAP applications considering quality parameters.

Karacay et al., (2010. a) studied the effect of microbial, physical, chemical and sensory qualities on peeled and segmented fruits packed under active and passive MAP with low oxygen $\left(20 \% \mathrm{O}_{2}, 10 \% \mathrm{CO}_{2}, 70 \% \mathrm{~N}_{2}\right)$ and high oxygen $\left(80 \% \mathrm{O}_{2}, 10 \% \mathrm{CO}_{2}, 10 \% \mathrm{~N}_{2}\right)$ in PP trays sealed with cpp film stored at $4^{0} \mathrm{C}$ for 25 days. Results showed that no significant microbial growth and slight changes in acidity and brix of orange segments. Increased hardness and decreased colour of segments during storage period. Orange segments remained in a commercially viable condition for 10 days under MAP.

The objective of this study was to investigate microbiological and sensorial quality of "ready to eat" orange segments that packaged under three different modified atmospheres: $\mathrm{G}_{1}, \mathrm{G}_{2}$ and $\mathrm{G}_{3}$ using three different packaging materials i.e., LDPE, PP and PVC pouches at $5^{\circ} \mathrm{C}$ during storage period.

\section{Materials and Methods}

Fresh and matured orange fruits used for the study were procured from fruit market at Vijayawada, Krishna District. The fresh, healthy and defect free oranges were sorted out and selected for the study. Fresh and sorted orange fruits were sanitized by immersion in $200 \mathrm{ppm}$ sodium hypochlorite solution $(\mathrm{NaOCl})$ for 2 min to remove surface disinfection. Then they were rinsed with distilled water and wiped with tissue paper to remove the surface moisture. A solution was made with citric acid (food grade) at $2 \%$ $(w / v)$ dissolved in sterile distilled water at 
$5^{0} \mathrm{C}$. The fresh orange segments were dipped in this solution for $2 \mathrm{~min}$ and shade dried for $15 \mathrm{~min}$.

Citric acid treated and untreated orange segments were packed with different packaging materials i.e., LDPE, PP and PVC pouches under three different gas compositions i.e., Gas composition $1\left(\mathrm{G}_{1}: 8 \%\right.$ $\mathrm{O}_{2}+15 \% \mathrm{CO}_{2}+77 \% \mathrm{~N}_{2}$ ); Gas composition 2 $\left(\mathrm{G}_{2}: 5 \% \mathrm{O}_{2}+10 \% \mathrm{CO}_{2}+85 \% \mathrm{~N}_{2}\right) ; \mathrm{Gas}$ composition $3\left(\mathrm{G}_{3}: 3 \% \mathrm{O}_{2}+5 \% \mathrm{CO}_{2}+92 \%\right.$ $\mathrm{N}_{2}$ ) using advanced vacuum packaging machine. After packaging, the sealed covers and control samples of orange segments were immediately stored at $5^{\circ} \mathrm{C}$.

At an interval of 4 days, the stored samples of orange segments were taken for their quality evaluation i.e., microbial load and sensory evaluations were also conducted to establish consumer acceptance. Based on these characteristics, the shelf life of orange segments was assessed.

\section{Determination of microbial load}

Initially the petri plates, cotton swabs and water blanks were sterilized using an autoclave. Media for plate count agar, yeast (YEPDA) and fungal culture (MRBA) were prepared according to standard procedure. After autoclaving hot media was poured in each plate under sterile conditions and allowed to solidify. $10 \mathrm{~g}$ of fruit sample was placed into a water blank with $90 \mathrm{ml}$ of peptone water and samples were homogenized for $3 \mathrm{~min}$ and serial dilutions were made in peptone water.

Appropriate dilutions were plated onto duplicate plates of YEPDA, MRBA and Nutrient Agar medium and it was spread uniformly over the medium with a sterilized glass spreader and kept for incubation at $35^{\circ} \mathrm{C}$ for 24 to $48 \mathrm{~h}$. After $48 \mathrm{~h}$ plates were observed for growth and numbers of colonies $(\mathrm{X})$ were counted by visual observation. The results were presented as $\mathrm{CFU} / \mathrm{g}$.

Number of colonies $=\mathrm{X}$ colonies $\times$ serial dilution factor

\section{Sensory evaluation}

Orange segments packaged with different packaging materials under different gas composition were evaluated for visual appearance, aroma, texture, sweetness, and product acceptability using a five-point hedonic scale during 25 days of storage period (Khazaei et al., 2011). The sensory attributes were defined based on the important characteristics of orange. The score 3 was considered the limit of acceptance.

The testing panel was selected at random from the College of Agricultural Engineering, ANGRAU, Bapatla to assessed defined attributes and the scale during the trial period. The testing was done in a clean, quiet, airconditioned and odor free room where each panelist used separate tables during judgments. Specific attributes and acceptability were evaluated by the six untrained panelists on the basis of acceptability, using a scale ranging from 1 to 5 as follows (Karacay and Ayhan, 2010.a.).

Visual appearance: 5: excellent/fresh; 4: good; 3: acceptable; 2: poor; 1: very poor

Aroma: 5: very good/natural; 4: good; 3: acceptable; 2: light strange aroma; 1: strong strange aroma

Texture: 5: excellent firmness/juiciness; 4: firm/juicy; 3: acceptable; 2: hard/dry; 1: very hard/dry

Acidity: 5: very good; 4: good; 3: acceptable; 2: acidic; 1: very acidic 
Sweetness: 5: very sweet; 4: sweet; 3: acceptable sweetness; 2: poor in sweetness; 1 : not sweet

Product acceptability: 5: excellent; 4: good; 3: acceptable; 2 : bad; 1 : very bad

\section{Results and Discussion}

\section{Microbial evaluation of stored orange} segments

The microbial growth i.e., yeast, mould and standard count of treated and untreated orange segments packed in different packaging covers, namely LDPE, PP and PVC covers under different gas compositions i.e., $\mathrm{G}_{1}, \mathrm{G}_{2}$ and $\mathrm{G}_{3}$ stored at refrigerated temperature $\left(5^{0}\right.$ C) and control samples were determined. The results were shown in the Table $1,2 \& 3$.

It is observed from the Table $1 \& 2$, there was no microbial growth observed in first 12 days of storage period of citric acid treated orange segments. In $\mathrm{G}_{2}$ gas composition, yeast and mould growth started at $20 \& 25^{\text {th }}$ day in LDPE packed untreated and treated orange segments respectively. In $\mathrm{G}_{3}$ gas composition, yeast growth $\left(1 \times 10^{4} \mathrm{CFU} / \mathrm{g}\right)$ started at $12^{\text {th }} \&$ $16^{\text {th }}$ day in PVC packed untreated and treated orange segments respectively.

Mould growth $\left(1 \times 10^{4} \mathrm{CFU} / \mathrm{g}\right)$ started at $12^{\text {th }} \&$ $16^{\text {th }}$ day in PVC packed untreated and treated orange segments under $\mathrm{G}_{3}$ gas composition respectively. High yeast $\left(3 \times 10^{4} \mathrm{CFU} / \mathrm{g}\right)$ and mould $\left(4 \times 10^{4} \mathrm{CFU} / \mathrm{g}\right)$ counts were observed in unpacked (control) orange segments. Yeast and mould counts were high in both treated and untreated orange segments packed in PVC covers under $\mathrm{G}_{3}$ gas composition compared to LDPE and PP covers. In $\mathrm{G}_{3}$ gas composition, very low oxygen attributed to anaerobic atmosphere which could be risky for consumption.
In Table 3, the microbial growth (standard count) of untreated and treated orange segments packed in three packaging materials under three gas compositions were observed on $12^{\text {th }} \& 16^{\text {th }}$ day of storage period. The high standard count was observed in PVC covers under $\mathrm{G}_{1}$ and $\mathrm{G}_{3}$ gas compositions. The less standard count observed in treated orange segments packed in LDPE covers under $G_{2}$ gas composition. Highest standard count $\left(5 \times 10^{4} \mathrm{CFU} / \mathrm{g}\right)$ was observed in control samples.

Further, it was also observed that yeast, mould and standard count was high in control and untreated orange segments compared to treated orange segments because citric acid is an organic acid, it lowers the $\mathrm{pH}$ of the product (Chaves et al., 2013). Sanitation with $200 \mathrm{ppm} \mathrm{NaOCl}$ before peeling lowers the $\mathrm{pH}$ of the product and modified atmosphere combined with low storage temperature provided good microbial quality (Karacay and Ayhan, 2010. b). Lower $\mathrm{pH}$ inhibits the growth of pathogens harmful to human health, helping the conservation of foods. Less yeast, mould and standard count was observed in treated orange segments packed in LDPE covers under $\mathrm{G}_{2}$ gas composition.

\section{Sensory evaluation on quality of orange segments}

A sensory evaluation method adopted for the analysis of acceptability of the orange segments with the help of 5 point hedonic scale (Karacay and Ayhan, 2010.a). The hedonic scale used for the testing of various quality parameters were given below.

\section{Visual appearance}

From the Fig. 1, the visual appearance was high under $\mathrm{G}_{2}$ gas composition compared to $\mathrm{G}_{1} \& \mathrm{G}_{3}$ gas compositions. The unpacked (control) orange segments were stored at $5^{\circ} \mathrm{C}$ 
showed a low rating (3.03) of visual appearance. The visual appearance of orange segments was good in LDPE films compared to PP, PVC films. The visual appearance rating of stored treated orange segments packed in LDPE covers under $\mathrm{G}_{2}$ gas composition obtained a high rating (4.45) on the hedonic scale.

Table.1 Variation in yeast count $(\mathrm{CFU} / \mathrm{g})$ during storage period of untreated, treated and control samples of orange segments under MAP at $5^{\circ} \mathrm{C}$

\begin{tabular}{|c|c|c|c|c|c|c|c|c|c|c|}
\hline \multicolumn{11}{|c|}{ Yeast count $\left(10^{4} \mathrm{CFU} / \mathrm{g}\right)$} \\
\hline \multicolumn{11}{|c|}{ Untreated Orange Segments } \\
\hline \multirow{2}{*}{ Days } & \multicolumn{3}{|c|}{$\mathbf{G}_{1}$} & \multicolumn{3}{|c|}{$\mathbf{G}_{\mathbf{2}}$} & \multicolumn{3}{|c|}{$\mathbf{G}_{\mathbf{3}}$} & \multirow{2}{*}{ Control } \\
\hline & LDPE & PP & PVC & LDPE & PP & PVC & LDPE & $\mathbf{P P}$ & PVC & \\
\hline 0 & - & - & - & - & - & - & - & - & - & - \\
\hline 4 & - & - & - & - & - & - & - & - & - & 4 \\
\hline 8 & - & - & - & - & - & - & - & - & - & \\
\hline 12 & - & - & - & - & - & - & - & 1 & 2 & \\
\hline 16 & 1 & 1 & 1 & - & - & 1 & 1 & 1 & 2 & \\
\hline 20 & 1 & 1 & 2 & 1 & 1 & 1 & 1 & 1 & 2 & \\
\hline \multicolumn{11}{|c|}{ Treated Orange Segments } \\
\hline \multirow{2}{*}{ Days } & \multicolumn{3}{|c|}{$\mathbf{G}_{1}$} & \multicolumn{3}{|c|}{$\mathbf{G}_{2}$} & \multicolumn{3}{|c|}{$\mathbf{G}_{\mathbf{3}}$} & \multirow{2}{*}{ Control } \\
\hline & LDPE & PP & PVC & LDPE & PP & PVC & LDPE & PP & PVC & \\
\hline 0 & - & - & - & - & - & - & - & - & - & - \\
\hline 4 & - & - & - & - & - & - & - & - & - & 4 \\
\hline 8 & - & - & - & - & - & - & - & - & - & \\
\hline 12 & - & - & - & - & - & - & - & - & - & \\
\hline 16 & - & 1 & 1 & - & - & - & 1 & 1 & 1 & \\
\hline 20 & 1 & 1 & 1 & - & - & 1 & 1 & 2 & 2 & \\
\hline 25 & 1 & 1 & 2 & 1 & 1 & 1 & 1 & 2 & 3 & \\
\hline
\end{tabular}

Fig.1 Variation in visual appearance during storage period of untreated and treated orange segments packed in different packaging materials under different gas compositions at $5^{\circ} \mathrm{C}$

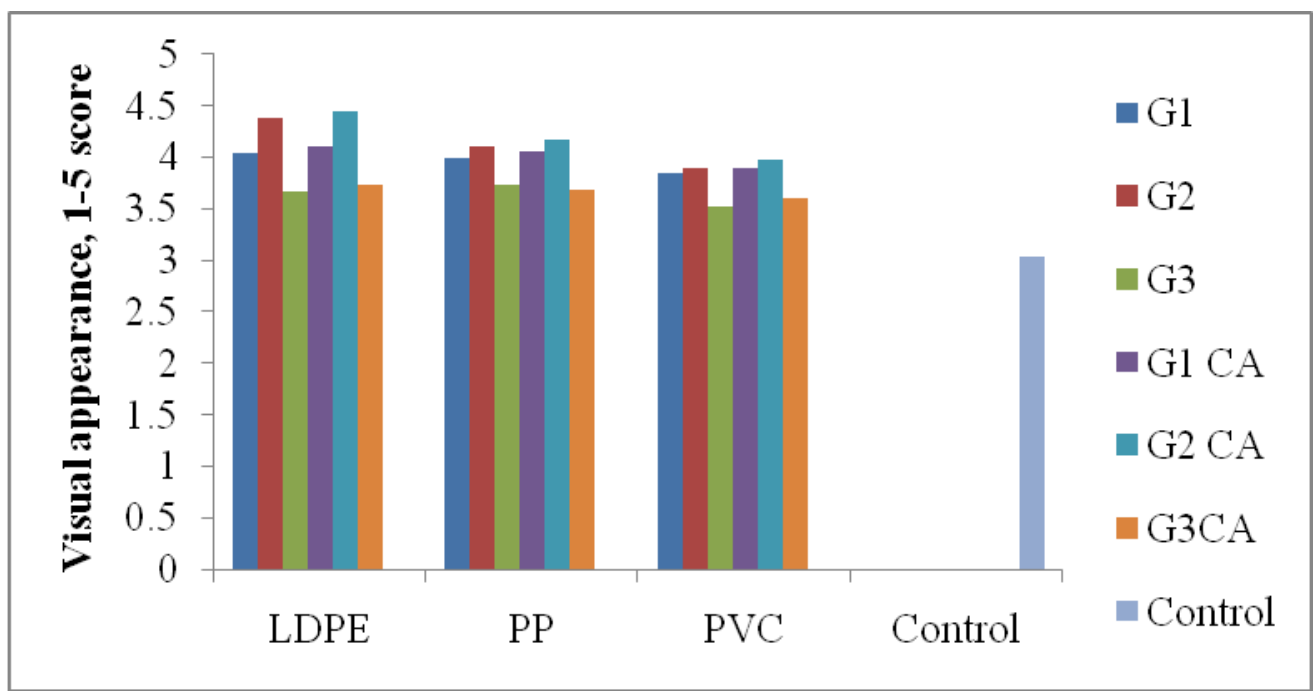


Table. 2 Variation in mould count $(\mathrm{CFU} / \mathrm{g})$ during storage period of untreated, treated and control samples of orange segments under MAP at $5^{\circ} \mathrm{C}$

\begin{tabular}{|c|c|c|c|c|c|c|c|c|c|c|}
\hline \multicolumn{11}{|c|}{ Mould count ( $\left.10^{4} \mathrm{CFU} / \mathrm{g}\right)$} \\
\hline \multicolumn{11}{|c|}{ Untreated Orange Segments } \\
\hline \multirow{2}{*}{ Days } & \multicolumn{3}{|c|}{$\mathbf{G}_{1}$} & \multicolumn{3}{|c|}{$\mathbf{G}_{\mathbf{2}}$} & \multicolumn{3}{|c|}{$\mathbf{G}_{\mathbf{3}}$} & \multirow{2}{*}{ Control } \\
\hline & LDPE & $\mathbf{P P}$ & PVC & LDPE & $\mathbf{P P}$ & PVC & LDPE & $\mathbf{P P}$ & PVC & \\
\hline 0 & - & - & - & - & - & - & - & - & - & - \\
\hline 4 & - & - & - & - & - & - & - & - & - & 3 \\
\hline 8 & - & - & - & - & - & - & - & - & - & \\
\hline 12 & - & - & - & - & - & - & - & 1 & 2 & \\
\hline 16 & - & 1 & 1 & - & 1 & 1 & 1 & 1 & 2 & \\
\hline 20 & - & 2 & 2 & 1 & 1 & 1 & 1 & 1 & 2 & \\
\hline \multicolumn{11}{|c|}{ Treated Orange Segments } \\
\hline \multirow{2}{*}{ Days } & \multicolumn{3}{|c|}{$\mathbf{G}_{1}$} & \multicolumn{3}{|c|}{$\mathbf{G}_{2}$} & \multicolumn{3}{|c|}{$\mathbf{G}_{3}$} & \multirow{2}{*}{ Control } \\
\hline & LDPE & $\mathbf{P P}$ & PVC & LDPE & $\mathbf{P P}$ & PVC & LDPE & $\mathbf{P P}$ & PVC & \\
\hline 0 & - & - & - & - & - & - & - & - & - & - \\
\hline 4 & - & - & - & - & - & - & - & - & - & 3 \\
\hline 8 & - & - & - & - & - & - & - & - & - & \\
\hline 12 & - & - & - & - & - & - & - & - & - & \\
\hline 16 & - & - & - & - & - & 1 & - & 1 & 1 & \\
\hline 20 & 1 & 1 & 1 & - & 1 & 1 & 1 & 1 & 1 & \\
\hline 25 & 1 & 1 & 2 & 1 & 1 & 1 & 1 & 2 & 2 & \\
\hline
\end{tabular}

Fig.2 Variation in aroma during storage period of untreated and treated orange segments packed in different packaging materials under different gas compositions at $5^{\circ} \mathrm{C}$

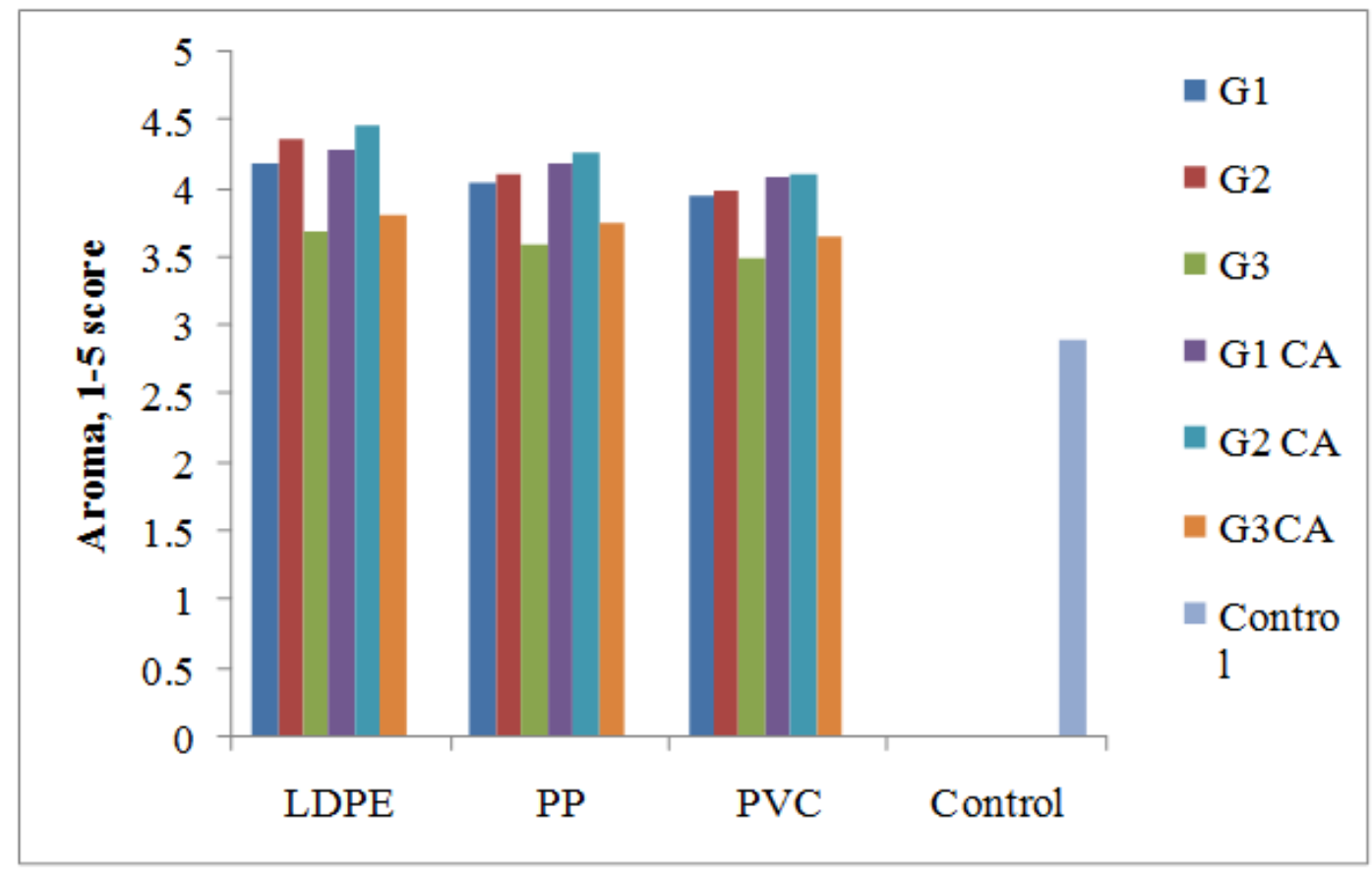


Table.3 Variation in standard count (CFU/g) during storage period of untreated, treated and control samples of orange segments under MAP at $5^{\circ} \mathrm{C}$

\begin{tabular}{|c|c|c|c|c|c|c|c|c|c|c|}
\hline \multicolumn{11}{|c|}{ Standard count $\left(10^{4} \mathrm{CFU} / \mathrm{g}\right)$} \\
\hline \multicolumn{11}{|c|}{ Untreated Orange Segments } \\
\hline \multirow{2}{*}{ Days } & \multicolumn{3}{|c|}{$\mathbf{G}_{1}$} & \multicolumn{3}{|c|}{$\mathbf{G}_{\mathbf{2}}$} & \multicolumn{3}{|c|}{$\mathbf{G}_{3}$} & \multirow{2}{*}{ Control } \\
\hline & LDPE & PP & PVC & LDPE & $\mathbf{P P}$ & PVC & LDPE & $\mathbf{P P}$ & PVC & \\
\hline 0 & - & - & - & - & - & - & - & - & - & - \\
\hline 4 & - & - & - & - & - & - & - & - & - & 5 \\
\hline 8 & - & - & - & - & - & - & - & - & - & \\
\hline 12 & - & - & 2 & - & - & 1 & 1 & - & 2 & \\
\hline 16 & 1 & 1 & 2 & 1 & 1 & 1 & 1 & 2 & 2 & \\
\hline 20 & 1 & 2 & 3 & 1 & 1 & 2 & 1 & 2 & 3 & \\
\hline \multicolumn{11}{|c|}{ Treated Orange Segments } \\
\hline \multirow{2}{*}{ Days } & \multicolumn{3}{|c|}{$\mathbf{G}_{1}$} & \multicolumn{3}{|c|}{$\mathbf{G}_{2}$} & \multicolumn{3}{|c|}{$\mathbf{G}_{3}$} & \multirow{2}{*}{ Control } \\
\hline & LDPE & PP & PVC & LDPE & $\mathbf{P P}$ & PVC & LDPE & $\mathbf{P P}$ & PVC & \\
\hline 0 & - & - & - & - & - & - & - & - & - & - \\
\hline 4 & - & - & - & - & - & - & - & - & - & 5 \\
\hline 8 & - & - & - & - & - & - & - & - & - & \\
\hline 12 & - & - & - & - & - & - & - & - & - & \\
\hline 16 & - & - & - & - & - & - & - & - & 1 & \\
\hline 20 & 1 & 1 & 1 & - & 1 & 2 & 1 & 1 & 2 & \\
\hline 25 & 1 & 2 & 2 & 1 & 1 & 1 & 1 & 2 & 2 & \\
\hline
\end{tabular}

Fig.3 Variation in texture during storage period of untreated and treated orange segments packed in different packaging materials under different gas compositions at $5^{\circ} \mathrm{C}$

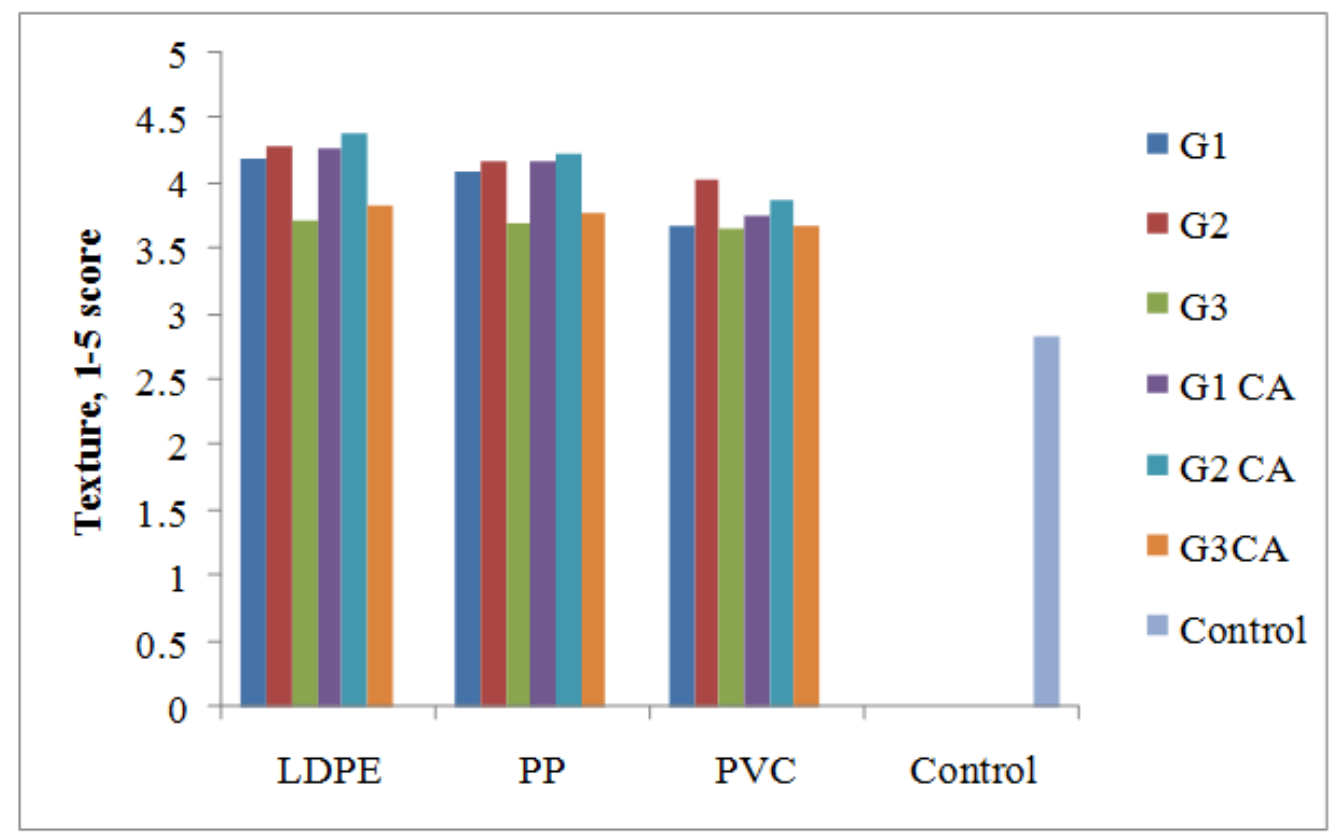


Fig.4 Variation in sweetness during storage period of untreated and treated orange segments packed in different packaging materials under different gas compositions at 50C

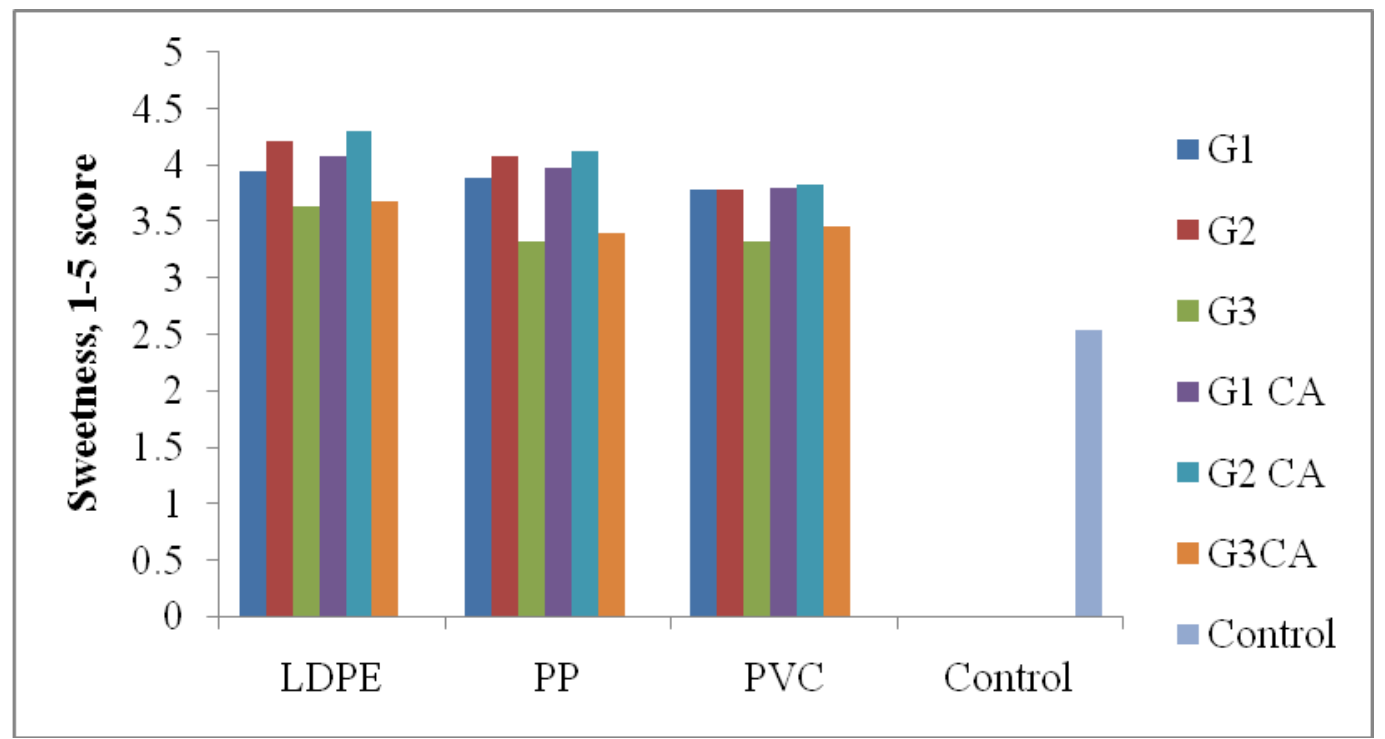

Fig.5 Variation in product acceptability during storage period of untreated and treated orange segments packed in different packaging materials under different gas compositions at 50C

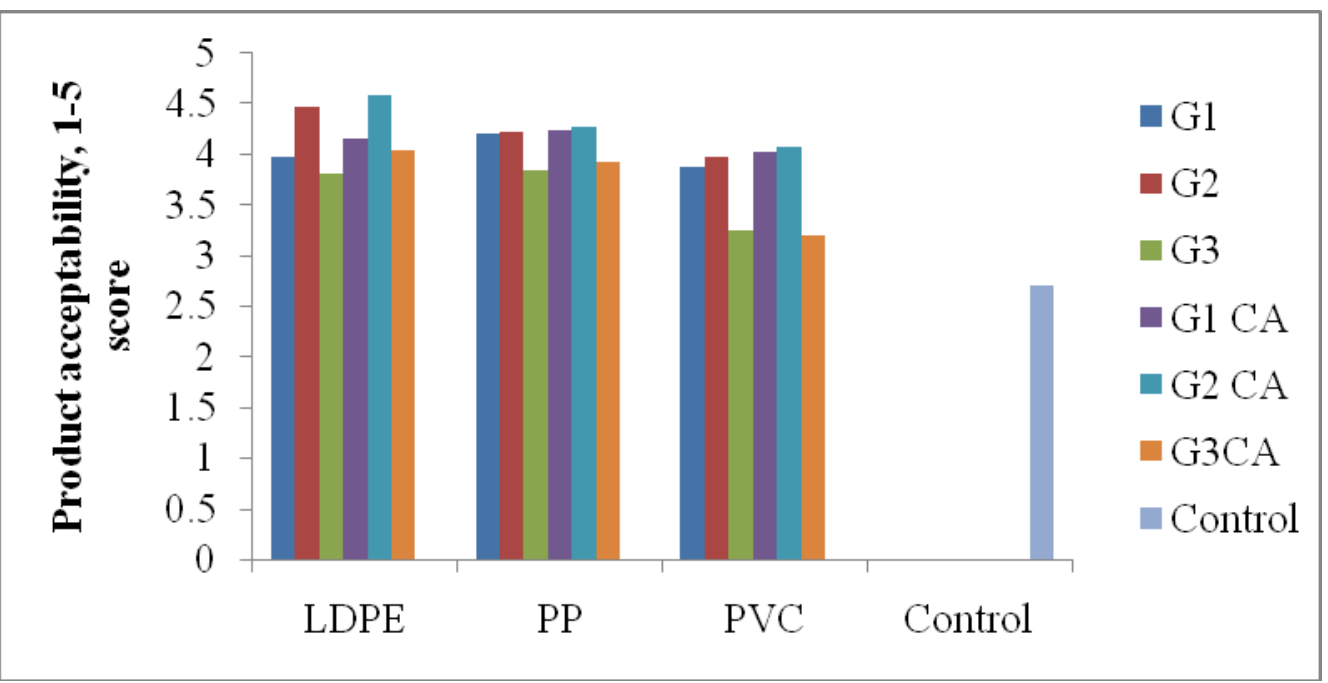

\section{Aroma}

It was observed from the Fig. 2, the unpacked orange segments (control) stored at $5^{\circ} \mathrm{C}$ had low rating value (2.9) on the hedonic scale i.e., the rating was in below the acceptable limit (3.0). The aroma of treated orange segments was very good under MAP conditions as compared to untreated orange segments under $\mathrm{G}_{1}, \mathrm{G}_{2} \quad \& \quad \mathrm{G}_{3}$ gas compositions. The aroma rating was good in LDPE covers than PP and PVC covers. The aroma of treated orange segments packed in LDPE covers under $\mathrm{G}_{2}$ gas composition 
obtained a high rating (4.47) on the hedonic scale compared to PP and PVC covers.

\section{Texture}

The texture of orange segments was observed visually and feels by touch. From the Fig. 3, it is observed that the unpacked orange segments (control) stored at $5^{0} \mathrm{C}$ showed a low rating (2.83) of texture. The texture of orange segments was good in LDPE films compared to PP, PVC films and unpacked control orange segments. The texture was high under $\mathrm{G}_{2}$ gas composition compared to $\mathrm{G}_{1} \& \mathrm{G}_{3}$ gas compositions. The stored treated orange segments packed in LDPE covers under $\mathrm{G}_{2}$ gas composition obtained a high rating (4.38) on the hedonic scale.

\section{Sweetness}

The sweetness of orange segments was observed by the taste. It was observed from the Fig. 4, the unpacked orange segments (control) stored at $5^{0} \mathrm{C}$ obtained a low rating (2.53) on the hedonic scale. The sweetness of packed orange segments was very good under MAP conditions packed in LDPE covers than PP, PVC covers and unpacked (control) orange segments. The sweetness of stored orange segments packed in LDPE covers under $\mathrm{G}_{2}$ gas composition obtained a high rating (4.3) on the hedonic scale.

\section{Product Acceptability}

It is observed from the Fig. 5, the unpacked (control) orange segments stored at $5^{\circ} \mathrm{C}$ showed a low rating (2.7) of product acceptability. The product acceptability of orange segments was good in LDPE films compared to PP, PVC films and unpacked (control) orange segments. The product acceptability was high under $\mathrm{G}_{2}$ gas composition compared to $\mathrm{G}_{1} \& \mathrm{G}_{3}$ gas compositions. The product acceptability of stored treated orange segments packed in LDPE covers under $\mathrm{G}_{2}$ gas composition obtained a high rating (4.58) on the hedonic scale.

In summary, the sensory attributes and product acceptance of orange segments were determined for three different gas compositions at three different packing covers during storage. Considering all sensory attributes, PVC covers were unacceptable (<3) for 25 days storage. This is due to high permeability of PVC covers compared to LDPE and PP covers. Aroma, visual appearance, sweetness, texture and product acceptability scores were decreased by increase in storage period. The sensory attributes of three packing covers under three gas compositions were in acceptable limit (3.0) up to 12 days of storage period. The unpacked (control) orange segments showed low acceptance, thus being considered unfit for consumption.

The product acceptability and sensory attributes of untreated and treated orange segments under $\mathrm{G}_{1}$ gas composition were limited to 16 and 20 days. This may be due to high carbon dioxide. The product acceptance and sensory attributes of untreated and treated segments under $\mathrm{G}_{3}$ gas composition was limited to 12 and 16 days. This may probably the negative effect of very low oxygen attributed to anaerobic atmosphere which could be risky for consumption. In $\mathrm{G}_{2}$ gas composition, untreated and treated orange segments were limited to 20 and 25 days due to oxygen concentration and sensory quality and the results suggested that quality was better in orange segments packed in LDPE covers under $\mathrm{G}_{2}$ gas composition for 25 days.

\section{References}

Chaves, K.F., Cruz, W.F., Rocha D.T., Oliveira M.A.D., Silva, V.R.O and 
Silva, M.H.L. 2013. Minimally processed 'Pera' orange: effect of antioxidant agents on the sensorial acceptance and physicochemical characteristics. Int. J. Postharvest Technol. Innovation, 3(2): 165-176.

Groppo, V.D., Spoto, M.H.F., Gallo, C.R and Sarmento, S.B.S. 2009. Effect of calcium chloride and film of sodium alginate in the conservation of minimally processed 'Pera' orange. $J$. Food Sci. Technol., 29(1): 107-113.

Karacay, E and Ayhan, Z. 2010. a. Microbial, physical, chemical and sensory qualities of minimally processed and modified atmosphere packaged "ready to eat" orange segments. Int. J. Food Properties, 13: 960-971.

Karaçay, E. and Ayhan, Z. 2010. b. Physiological physical chemical characteristics and sensory evaluation of minimally processed grapefruit segments packaged under modified atmosphere. J. Agri. Sci., 16: 129-138.

Khazaei, N., Jouki, M and Jouki, A. 2011. Effects of modified atmosphere packaging on physico-chemical characteristics and sensory evaluation of bitter orange (Citrus aurantium). Indian J. Agri. Sci., 81(11): 1014-1018.

Kumar, B., Mistry, N.C., Singh, B and
Gandhi, C.P. 2013. Commodity wise status (Chap 2) in Indian Horticulture Database 2013, Published by National Horticulture Board, Ministry of Agriculture, Gurgaon. P: 55.

Piga, A., Agabbio, M., Gambella, F and Nicoli, M.C. 2002. Retention of antioxidant activity in minimally processed mandarin and satsuma fruits. Lebensmittel-Wissenschaft undTechnologie. 35: 344-347.

Plaza, L., Crespo, I., de Pascual-Teresa, S., de Ancos, B., Sánchez-Moreno, C., Muñoz, M and Cano, M.P. 2011. Impact of minimal processing on orange bioactive compounds during refrigerated storage. Food Chem., 124: 646-651.

Pretel, M.T., Fernandez, P.S., Romojaro, F and Martinez, A. 1998. The effect of modified atmosphere packaging on 'ready-to-eat' oranges. LebensmittelWissenschaft und-Technologie, 31(4): 322-328.

Saxena, A., Bawa A.S and Raju, P.S. 2008. Use of modified atmosphere packaging to extend shelf-life of minimally processed jackfruit (Artocarpus heterophyllus L.) bulbs. J. Food Engi., 87(4): 455-466.

\section{How to cite this article:}

Gowthami, E., K. Lavanya, Sivala Kumar and Sandhya M. 2017. Microbial and Sensory Qualities of Modified Atmosphere Packaged "Ready To Eat" Orange Segments. Int.J.Curr.Microbiol.App.Sci. 6(2): 1225-1234. doi: http://dx.doi.org/10.20546/ijcmas.2017.602.139 